\title{
中学校の運営方式・校舎タイプによる掲示空間利用の比較 小中学校に打ける情報伝達手段としての掲示空間の計画に関する研究 その 2 COMPARISON OF USE OF WALL SPACE AMONG JUNIOR HIGH SCHOOLS WITH DIFFERENT CLASS SYSTEMS AND TYPES OF SCHOOL BUILDINGS
}

Research on the use of wall space as means of information dissemination in elementary and junior high schools Part 2

\author{
大崎 淳 史*, 吉村 彰** \\ Atsushi OSAKI and Akira YOSHIMURA
}

\begin{abstract}
In this study, the number and contents of notices and posters on the walls in and around classrooms were surveyed for 6 junior high schools with different class systems and types of school buildings. It was found that (1) the number of notices and posters in schools adopting the departmental system is greater than that in schools adopting the conventional fixed-classroom system. (2) The number of notices and posters related to school life in schools adopting the departmental system is slightly lower than that in schools adopting the fixed-classroom system, whereas the number of notices and posters related to each subject is greater.
\end{abstract}

Keywords : junior high schools, departmental system, fixed-classroom system, classrooms, information dissemination, notices and posters

中学校，教科教室型運営方式，特別教室型運営方式，教室，情報伝達，掲示物

\section{1.はじめに}

\section{1 研究の背景と目的}

近年、中学校において教科教室型運営方式を採用する事例がふえ ている。校舎には、教科教室群やメディアセンター的オープンスペ ース（以下、オープンスペースをO S とする）からなる学習ゾーン と、ホームベース群（以下、ホームベースをH B とする）や共通ス クエアからなる生活ゾーンを一体的に構成する特徵が見られる。

中学校は、小学校のように 1 人の教師が全教科を教える学級担任 制とは異なり教科ごとに担当教師が教える教科担任制である。それ ぞれの担当教師が独自の判断で教室環境を変えるのは難しい。その ため従来から「特別教室型運営方式の学級教室では積極的な教材の 掲示につながらない、学年ごとにO S を取り入れたケースでもO S で教師が互いに協力し学習環境を作り込むには至らない」などが指 摘されてきた ${ }^{1)}$ 。教科教室型運営方式はこうした課題の抜本的改善 を果たす計画手法として着目されている。しかしその一方で、近年 の教科教室型事例は校舎に中庭を取り入れ空壁を多用することで明 るく見通しのよい計画とする場合が多く、このケースでは掲示面の 確保は難しいと考えられる。さらに多くの学校が R C 造を採用寸る ことから、壁面の構造によっては揭示範囲を大きく限定してしまう
と考えられる。

教科教室型に限らず従来型（特別教室型）も含め、中学校の教室 まわりでは具体的にどのように掲示が行われているのかはあまり明 らかにされていない。そのため掲示空間の計画は、明確な指標に乏 しく、設計者の良識に任される状況がつづいている。そこで本研究 では、中学校における教室まわりの情報伝達手段としての掲示空間 のあり方について建築計画的知見を得ることを目的として、教科教 室型運営方式・O S 導入校を含む中学校を対象に教室まわりの掲示 空間利用の実態を把握し、運営方式・校舎タイプによる比較分析を 行う。

\section{2 研究の位置づけ}

学校の掲示環境をテーマにした先行研究はいくつかあげられる が、掲示空間利用を把握する上で詳細な掲示実態を明らかにした例 はほとんど見られない2３３４４５）6）7。中学校を対象としたものと なると皆無に等しい。筆者らはすでに、O S 導入校を含む小学校を 対象に教室まわりの掲示空間利用の実態を把握すると共に、掲示に 対する教師の意識を把握し、校舎タイプによる比較分析を行ってい

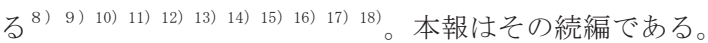

\footnotetext{
本報は, 日本建築学会・第30回地域施設計画研究シンポジウム(2012年 7 月開催)で報告した研究文17) 大幅に加筆・修正したものである。

* 東京電機大学情報環境学部＼cjkstart助教・博士(工学)－Assistant Prof., Faculty of Information Environment, Tokyo Denki Univ., Dr. Eng.

***東京電機大学情報環境学部＼cjkstart教授・博士（工学）Ｐrof., Faculty of Information Environment, Tokyo Denki Univ., Dr. Eng.
} 


\section{2. 研究の対象と方法}

対象校には、千葉県印西市立木刈中学校 (木刚中)、茨城県つく ばみらい市立小絹中学校 (小絹中) 、千葉県印西市立西の原中学校 (西 の原中)、千葉県白井市立桜台中学校（桜台中）、福井県福井市立至 民中学校（至民中） ${ }^{19)}$ 、福井県坂井市立丸岡南中学校（丸岡南中） 20)の 6 校を選定した（表 1 ）注1）。

対象校は、運営方式として特別教室型と教科教室型、さらに校舎 の空間構成として片廊下タイプとOSタイプに分けることができ る。(1)木刚中、小絹中、西の原中は、普通教科を学級教室で行い特 別教科を専門の教室で行う運営方式で、校舎が廊下の片側に面して 学級教室を並べた空間構成となっている「特別教室型・片廊下タイ プ」(写真 1 )。(2)桜台中は、特別教室型運営方式で、校舎が学年ご とに学級教室に隣接してOS を配置した空間構成となっている「特 別教室型・OSタイプ」(写真 2)。(3)至民中、丸岡南中は、全教科 で専門の教室があり生徒が時間割に沿って教室を移動する運営方式 で、校舎が英語・国語・数学・理科・社会、大きく 5 つの教科教室 群およびO S からなる学習ゾーンと、異学年の学級グループを 1 ユ ニットとしたHB 群および共通スクエアからなる生活ゾーンを一体 的に組み合わせた空間構成となっている「教科教室型・O S タイプ」 (写真 3 )。

調查方法として、各学年 1 学級分 $(6$ 校 $\times$ 各学年 1 学級 $=$ 計 18 学級分）の教室まわりにおける床面積、壁面積（空・扉を含む）、 掲示物の量 (縦横面積) - 内容 - 配置 - 掲示手段 - 掲示面構造を実 測した。実測範囲は、(1)木刈中、小絹中、西の原中（特別教室型 片廊下タイプ）が各学年の学級教室 1 室および廊下接続部分、(2)桜 台中（特別教室型・O S タイプ）が各学年の学級教室 1 室およびO S、(3)至民中、丸岡南中（教科教室型・O S タイプ）が 5 教科にお ける教科教室 1 室およびO S かつ各学年のH B 1 室および共通スク エアとした（図 1)。実測対象教室の選定は、揭示量が充実し整理 整頓された教室とした。調査期間は 2010 年 11 月〜 2011 年 11 月で ある注2)

\section{3. 教室まわりの掲示量・壁面掲示率・単位床面積当たり総掲示量}

表 2 は、 1 学級当たりの教室まわりの床面積、壁面積、掲示量、 壁面掲示率および単位床面積当たり総掲示量を算出し ${ }^{i \geq 3)}$ 、運営方 式・校舎タイプで比較・検定したものである注4)。以下に各項目の 分析結果について述べる。

\section{1 教室まわりの床面積・壁面積}

まず 1 学級当たりの床面積は、木刈中、小絹中、西の原中（特別 教室型・片廊下タイプ） が $82.0 \sim 85.5 \mathrm{~m}^{2}$ 、桜台中（特別教室型・ O S タイプ）が $126.9 \mathrm{~m}^{2}$ 、至民中、丸岡南中（教科教室型・O S タ

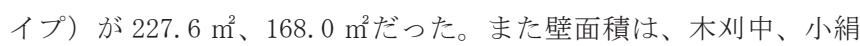
中、西の原中が $137.6 \sim 144.0 \mathrm{~m}^{2}$ 、桜台中が $124.2 \mathrm{~m}^{2}$ 、至民中、丸 岡南中が $263.5 \mathrm{~m}^{2} 、 245.7 \mathrm{~m}^{2}$ となっている。至民中、丸岡南中の 1 学級当たりの床面積、壁面積は校舎の規模に比例して広く大きいと いえる。床面積に対する壁面積の割合は、木刈中、小絹中、西の原 中の約 1.7 に対して、桜台中が約 1.0 、至民中、丸岡南中が約 1.2 、 約 1.5 となる。至民中は桜台中と同等、壁が疎に設定されていると いえる。一方、丸岡南中は木刈中、小絹中、西の原中と同等、壁が 密に設定されているといえる。
表 1 調查対象校概要

\begin{tabular}{|c|c|c|c|c|c|c|}
\hline 事例 & $\begin{array}{c}\text { 敷地面積 } \\
\left(\mathrm{m}^{2}\right)\end{array}$ & $\begin{array}{c}\text { 延床面積 } \\
\left(\mathrm{m}^{2}\right)\end{array}$ & $\begin{array}{c}\text { 全校 } \\
\text { 学級 }\end{array}$ & 運営方式 & 校舎タイプ & $\begin{array}{c}\text { 調査 } \\
\text { 時期 }\end{array}$ \\
\hline \hline 木刈中 & 31,234 & 6,854 & 11 & 特別教室型 & 片廊下タイプ & 2011.6 \\
\hline 小絹中 & 24,152 & 4,556 & 10 & 特別教室型 & 片廊下タイプ & 2011.6 \\
\hline 西の原中 & 31,573 & 5,087 & 11 & 特別教室型 & 片廊下タイプ & 2011.6 \\
\hline 桜台中 & 31,763 & 7,057 & 9 & 特別教室型 & O Sタイプ & 2011.11 \\
\hline 至民中 & 51,198 & 11,379 & 14 & 教科教室型 & O Sタイプ & 2010.11 \\
\hline 丸岡南中 & 37,181 & 10,980 & 14 & 教科教室型 & O Sタイプ & 2010.11 \\
\hline
\end{tabular}
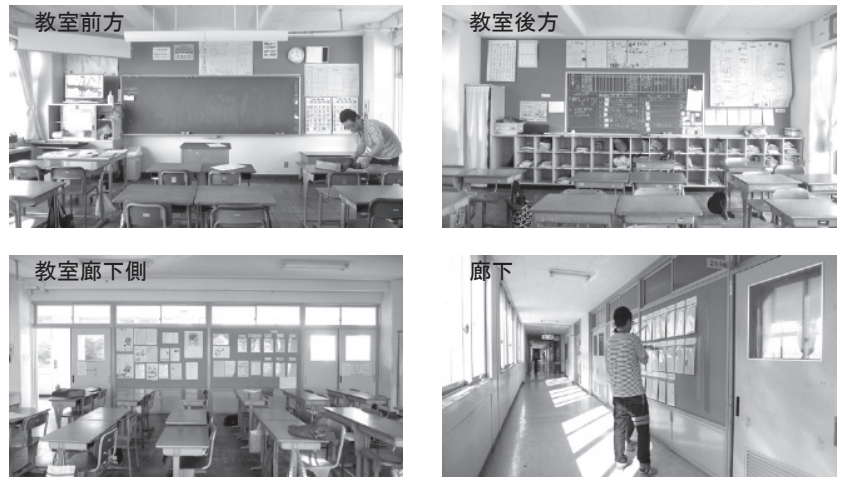

写真 1 木刚中（特別教室型・片廊下タイプ）
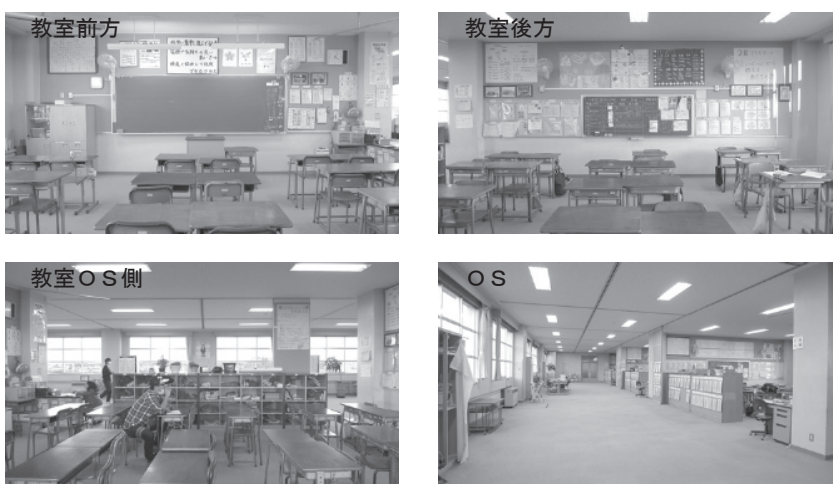

写真 2 桜台中 (特別教室型・O S タイプ)
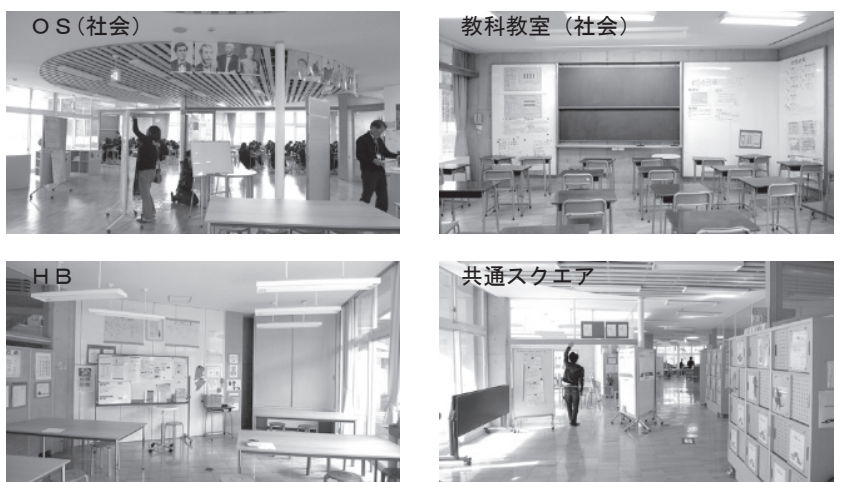

写真 3 至民中 (教科教室型・O S タイプ)

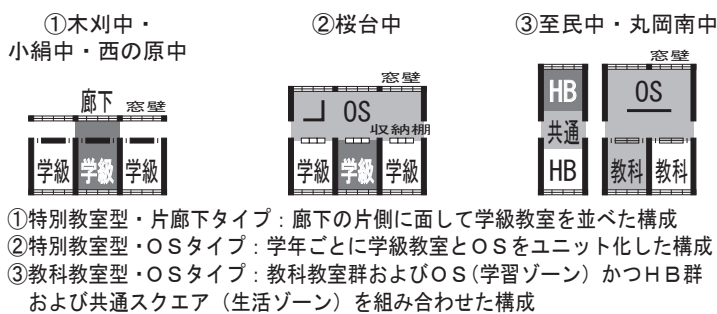

図 1 運営方式・校舎タイプ別空間構成 
表 2 教室まわりの掲示量・壁面掲示率・単位床面積当たり総掲示量（1学級当たり）結果および比較

\begin{tabular}{|c|c|c|c|c|c|c|c|c|c|c|c|c|c|c|c|c|c|c|c|c|c|}
\hline \multirow{2}{*}{\multicolumn{3}{|c|}{$\begin{array}{c}\text { 各校平均/全体平均／ } \\
\text { 運営方式·校坟タプ別平均／ } \\
\text { 比較検定 }\end{array}$}} & \multicolumn{7}{|c|}{ 床面積（ $\mathrm{m}^{2} ）$} & \multicolumn{7}{|c|}{ 壁面積 $\left(\mathrm{m}^{2}\right)$} & \multirow[b]{2}{*}{$\begin{array}{l}\text { 壁面掲 } \\
\text { 示量 } \\
\left(\mathrm{m}^{2}\right)\end{array}$} & \multirow[b]{2}{*}{$\begin{array}{c}\text { 壁面外 } \\
\left(\mathrm{m}^{2}\right)\end{array}$} & \multirow[b]{2}{*}{$\begin{array}{l}\text { 総掲示 } \\
\text { 量 }\left(\mathrm{m}^{2}\right)\end{array}$} & \multirow[b]{2}{*}{$\begin{array}{l}\text { 壁面掲 } \\
\text { 示率 }\end{array}$} & \multirow{2}{*}{$\begin{array}{l}\text { 単位床面 } \\
\text { 積当たり } \\
\text { 総掲示量 } \\
\left(\mathrm{m}^{2} / \mathrm{m}^{2}\right)\end{array}$} \\
\hline & & & $\begin{array}{l}\text { 学級 } \\
\text { 教室 }\end{array}$ & 廊下 & $\mathrm{HB}$ & 共通 & $\begin{array}{l}\text { 教科 } \\
\text { 教室 }\end{array}$ & os & 合計 & 学級 & 廊下 & HB & 共通 & \begin{tabular}{|l} 
教科 \\
教室
\end{tabular} & os & 合計 & & & & & \\
\hline \multirow{4}{*}{$\begin{array}{l}\text { 特別 } \\
\text { 教室型 }\end{array}$} & \multirow{3}{*}{$\begin{array}{l}\text { 片廊下 } \\
\text { タイプ }\end{array}$} & 木刈中 & 64.8 & 20.7 & & & & 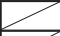 & 85.5 & 97.2 & 46.8 & & & & & 144.0 & 19.90 & 0.00 & 19.90 & $13.8 \%$ & 0.233 \\
\hline & & 小絹中 & 61.5 & 20.5 & $Z$ & $\angle$ & $\angle$ & $Z$ & 82.0 & 97.3 & 44.3 & $\angle$ & $Z$ & $\angle$ & $\angle$ & 141.6 & 13.55 & 0.00 & 13.55 & $9.6 \%$ & 0.165 \\
\hline & & 西の原中 & 64.0 & 18.4 & $\angle$ & $\angle$ & $z$ & $\angle$ & 82.4 & 96.0 & 41.6 & $Z$ & $Z$ & $\angle$ & $\angle$ & 137.6 & 18.61 & 0.00 & 18.61 & $13.5 \%$ & 0.226 \\
\hline & \multirow{3}{*}{$\begin{array}{l}\text { OS } \\
\text { タイプ }\end{array}$} & 桜台中 & 60.8 & & & & & 66.1 & 126.9 & 70.8 & & 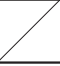 & & & \begin{tabular}{|l|}
53.4 \\
$(7.0)$ \\
\end{tabular} & $\begin{array}{l}124.2 \\
(7.0) \\
\end{array}$ & $\begin{array}{l}17.30 \\
(1.80) \\
\end{array}$ & 3. 92 & 21.22 & $\begin{array}{r}13.9 \% \\
(25.6 \% \\
\end{array}$ & 0.167 \\
\hline \multirow{2}{*}{$\begin{array}{l}\text { 教科 } \\
\text { 教室型 }\end{array}$} & & 至民中 & & & 40.4 & 36.1 & 82.7 & 68.4 & 227.6 & & & 62.9 & 17.8 & \begin{tabular}{|l|}
110.4 \\
$(1.1)$ \\
\end{tabular} & \begin{tabular}{|l|}
72.4 \\
$(2.1)$ \\
\end{tabular} & $\begin{array}{l}263.5 \\
(3.2) \\
\end{array}$ & $\begin{array}{l}19.32 \\
(0.98) \\
\end{array}$ & 8. 44 & 27.76 & \begin{tabular}{c|c}
$7.3 \%$ \\
$(30.5 \%)$ \\
\end{tabular} & 0.122 \\
\hline & & 丸岡南中 & & & 34.8 & 10.0 & 74.6 & 48.7 & 168.0 & & 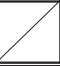 & 66.9 & 4. 0 & 127.8 & \begin{tabular}{|l|}
47.0 \\
$(10.5)$ \\
\end{tabular} & $\begin{array}{l}245.7 \\
(10.5) \\
\end{array}$ & $\begin{array}{l}19.89 \\
(2.83) \\
\end{array}$ & 1.96 & 21.85 & $\begin{array}{r}8.1 \% \\
(26.9 \%) \\
\end{array}$ & 0.130 \\
\hline \multicolumn{3}{|c|}{$\begin{array}{c}\text { 全体平均 } \\
\end{array}$} & & & & & & & 128.7 & & & & 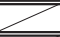 & $=$ & 71 & 1776.1 & 18.09 & 2.39 & 20.48 & $10.3 \%$ & 0.159 \\
\hline \multirow{2}{*}{\multicolumn{3}{|c|}{$\begin{array}{l}\text { (1)特別教室型・片廊下タイプ平均 } \\
\text { (2)特別教室型・Oタプ平均 }\end{array}$}} & & 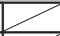 & - & $=$ & $=$ & $\sum$ & 83.3 & & 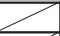 & 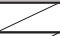 & $Z$ & 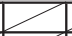 & & \begin{tabular}{ll|}
141.1 \\
\end{tabular} & 17.35 & 0.00 & 17.35 & $12.3 \%$ & 0.208 \\
\hline & & & 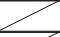 & 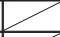 & 2 & 7 & $Z$ & $Z$ & 126.9 & 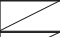 & 2 & $z$ & $Z$ & $Z$ & $\angle$ & 124.2 & 17.30 & 3.92 & 21.22 & $13.9 \%$ & 0.167 \\
\hline \multicolumn{3}{|c|}{ (3)教科教室型・OSタイプ平均 } & $=$ & $=$ & $=$ & $\angle$ & 2 & 2 & 197.8 & $=$ & $=$ & 2 & $=$ & $=$ & 2 & 254.6 & 19.60 & 5.20 & 24.80 & $7.7 \%$ & 0.125 \\
\hline \multicolumn{3}{|c|}{$\begin{array}{l}\text { 一元配置分散分析 } \\
\text { ** : } 1 \% \text { 有意 } \quad * \text { : } 5 \% \text { 有意 }\end{array}$} & & & & & & & ** & & & 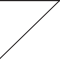 & 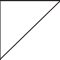 & & 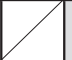 & ** & & ** & ** & ** & ** \\
\hline \multicolumn{22}{|c|}{ 多重比較（Tukey-Kramer法） } \\
\hline \multicolumn{3}{|c|}{ (1)-(2) } & $Z$ & 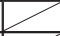 & 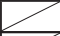 & 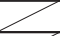 & 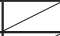 & 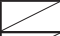 & ** & $\longrightarrow$ & 2 & 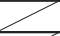 & $z$ & $Z$ & 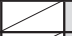 & ** & & * & & & \\
\hline \multirow{2}{*}{\multicolumn{3}{|c|}{$\frac{(1)-(3)}{(2)-(3)}$}} & $Z$ & 2 & $\angle$ & $\angle$ & 2 & $\angle$ & $* *$ & 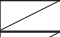 & 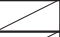 & $Z$ & $\angle$ & $Z$ & $Z$ & $* *$ & & ** & ** & ** & ** \\
\hline & & & 4 & 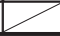 & 2 & 2 & $Z$ & $Z$ & ** & 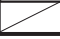 & & $z$ & $Z$ & 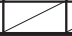 & $Z$ & ** & & & & ** & \\
\hline
\end{tabular}

※括弧は、可動間仕切壁に限定した場合の壁面積・壁面揭示量・壁面掲示率を示す。

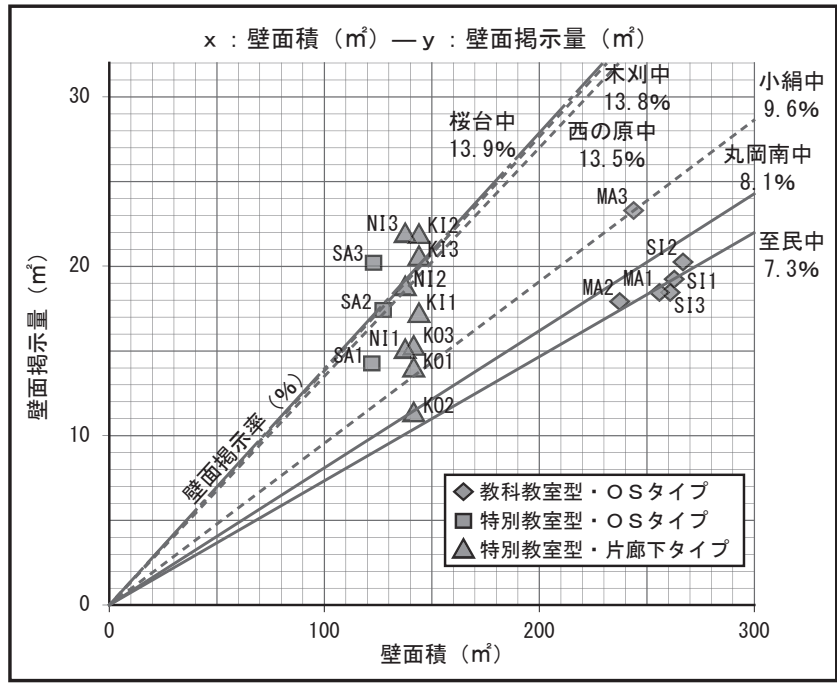

図 2 各学級の教室まわりの壁面積・壁面掲示量散布図

\section{2 掲示量}

掲示量については「壁面掲示量」「壁面外掲示量」、「総掲示量」 に分けて整理した。壁面掲示量はスライディングウォール（可動間 仕切壁）などを含めた壁全体（空や扉は壁の一部と見なす）におけ る掲示量を指寸。また、壁面外掲示量は天井や床、家具、掲示板な ど壁以外に貼られた掲示量を指す。総掲示量は壁面掲示量と壁面外 掲示量を合算した掲示量を表している。まず壁面掲示量としては、 木刈中、小絹中、西の原中が $13.55 \sim 19.90 \mathrm{~m}^{2}$ 、桜台中が 17.30 $\mathrm{m}^{2}$ 、至民中、丸岡南中が $19.32 \mathrm{~m}^{2} 、 19.89 \mathrm{~m}^{2}$ だった。運営方式・校 舎タイプの差はほとんどなく、いずれも全体平均 $18.09 \mathrm{~m}^{2} に$ 近い值 である。壁面外掲示量については、桜台中が $3.92 \mathrm{~m}^{2}$ 、至民中、丸

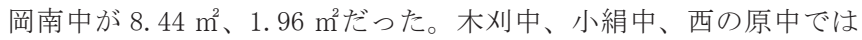
確認されなかった。総掲示量にまとめると、木刚中、小絹中、西の 原中が $13.55 \sim 19.90 \mathrm{~m}^{2}$ 、桜台中が $21.22 \mathrm{~m}^{2}$ 、至民中、丸岡南中が $27.76 \mathrm{~m}^{2} 、 21.85 \mathrm{~m}^{2}$ となり、至民中、丸岡南中の方が木刈中、小絹中、 西の原中よりも多くなる。比較的壁が疎に設定される桜台中、至民

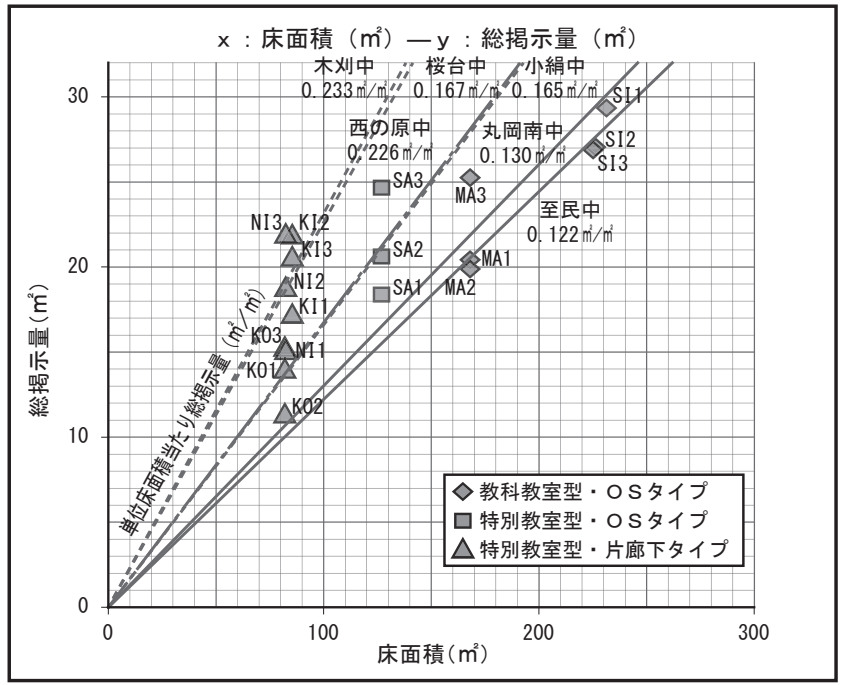

図 3 各学級の教室まわりの床面積・総掲示量散布図

中では、壁面外掲示を充実させているといえる。

至民中、丸岡南中における各教科学習ゾーンの 1 学級当たりの総 掲示量は、至民中の英語が $1.61 \mathrm{~m}^{2} 、$ 国語が $5.97 \mathrm{~m}^{2}$ 、数学が $4.56 \mathrm{~m}^{2}$ 、 理科が $6.56 \mathrm{~m}^{2}$ 、社会が $2.30 \mathrm{~m}^{2}$ となる。丸岡南中の英語が $3.63 \mathrm{~m}^{2}$ 、 国語が $2.26 \mathrm{~m}^{2}$ 、数学が $1.07 \mathrm{~m}^{2}$ 、理科が $2.30 \mathrm{~m}^{2}$ 、社会が $3.69 \mathrm{~m}^{2}$ と なる。至民中では国語、数学、理科が多く、丸岡南中では英語、社 会が多い。2 事例を見る限り、教科の性質による掲示要求の差はな いと考える。

\section{3 壁面掲示率および単位床面積当たり総掲示量}

図 2 は、壁面積を $\mathrm{x}$ 軸に、壁面掲示量を $\mathrm{y}$ 軸にとり、学級ごとに プロットした散布図である永5)。あわせて事例別に壁面揭示率（= 壁面掲示量／壁面積［\%]）を示している。図から、至民中、丸岡 南中は壁面積が大きい割に壁面掲示量がそれほど増していないこと が読み取れる。壁面掲示率を求めると、木刈中、小絹中、西の原 中が 9.6 〜 $13.8 \%$ 、桜台中が $13.9 \%$ 、至民中、丸岡南中が $7.3 \%$ 、 $8.1 \%$ となり、至民中、丸岡南中が比較的小さいことがわかる。 O S 、 
教科教室で掲示に向かない空壁が多いことが影響していると考えら れる。桜台中は壁面掲示率が最も大きいが、これは学級教室前方壁 面、後方壁面が掲示に有効に使われていること、O S では可動間仕 切壁が必要分引き出されやはり有効に使われていることによる。

図 3 は、床面積を $\mathrm{x}$ 軸に、総掲示量を $\mathrm{y}$ 軸にとり、学級ごとにプ ロットした散布図である注 6$)$ 。あわせて事例別に単位床面積当たり 総掲示量（=総掲示量／床面積 $\left.\left[\mathrm{m}^{2} / \mathrm{m}^{2}\right]\right)$ を示している。図から、 至民中、丸岡南中は木刈中、小絹中、西の原中より床面積が広く、 総掲示量も多いことが読み取れる。単位床面積当たり総掲示量を求 めると、木刈中、小絹中、西の原中が $0.165 \sim 0.233 \mathrm{~m}^{2} / \mathrm{m}^{2}$ 、桜台 中が $0.167 \mathrm{~m}^{2} / \mathrm{m}^{2}$ 、至民中、丸岡南中が $0.122 \mathrm{~m}^{2} / \mathrm{m}^{2} 、 0.130 \mathrm{~m}^{2} /$ $\mathrm{m}^{2}$ となる。至民中、丸岡南中は、単位床面積当たり総掲示量として は小さいものの、床面積が広い分、掲示量が増しているといえる。 床面積が広ければその分、掲示要求も増すと考えられる。

桜台中、至民中、丸岡南中では、可動間仕切壁の設定と掲示物の 配置を確認している。桜台中では 3 学年共通してO S の一角を可動 間仕切壁で囲んで着替えコーナーとし、外側を掲示スペースに利用 していた。第 2 学年については各学級で教室とO S の間に可動間仕 切壁を設定していた。1 学級当たり $7.0 \mathrm{~m}^{2} の$ 壁面積に対して 1.80 $\mathrm{m}^{2}$ の掲示量が確認できた。至民中では英語 $\mathrm{OS}$ および理科教室で可 動間仕切壁の設定が見られた。1 学級当たり $3.2 \mathrm{~m}^{2} の$ 壁面積に対し て $0.98 \mathrm{~m}^{2}$ の掲示量が確認できた。丸岡南中では全教科のOSで可 動間仕切壁（理科OSのみ掲示機能を高めた固定間仕切壁）の設定 が見られた。1 学級当たり $10.5 \mathrm{~m}^{2}$ の壁面積に対して $2.83 \mathrm{~m}^{2}$ の掲示 量が確認できた。

\section{4. 教室まわりの類型別掲示量 \\ 4. 1 掲示物の類型}

表 3 は、掲示物の内容を整理し類型化したものである。大きく分 けて生活類、学習類がある。さらに詳しく分類すると、生活類は(1) 学校教育目標やクラス目標、校歌といった「標語」、(2)学年便りや 時間割といった「生活の決まり・お知らせ」、(3)献立表や給食当番、 保健便りといった「給食·保健·衛生情報」、(4)学級組織表や班活動、 委員会活動といった「係・委員会等活動情報」、(5)生徒写真や行事 感想文といった「生活記録」、(6)高校入試案内や募金案内といった「学 外情報」、(7)絵画や写真、イラストといった「装飾」、8校舎案内や 避難経路図といった「学校案内」、(9)以上 8 項目に該当しない「先 の他の生活類」の 9 項目に分けることができる。学習類については (10)学習計画表や教具といった「教具」、(11)個人による学習記録・作 品「学習記録・作品 (個人)」、(12グループによる学習記録・作品「学 習記録・作品（集団）」の 3 項目に分けることができる。

\section{2 類型別掲示量}

表 4 は、1 学級当たりの類型別掲示量を算出し、運営方式・校 舎タイプで比較・検定したものである注7)。生活類合計は、木刈中、 小絹中、西の原中が $11.70 \sim 16.60 \mathrm{~m}^{2}$ 、桜台中が $19.62 \mathrm{~m}^{2}$ 、至民中、

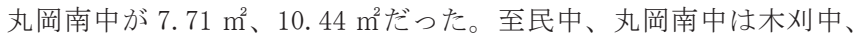
小絹中、西の原中、桜台中に比べて少ない。H B の床面積、壁面積 が木刈中、小絹中、西の原中、桜台中の学級教室（掲示の大半を生 活類掲示が占める）より狭く小さいことが影響している。一方、学 習類合計は、木刚中、小絹中、西の原中が $1.85 \sim 3.30 \mathrm{~m}^{2}$ 、桜台中

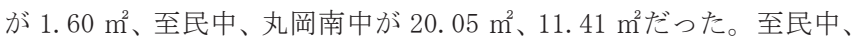
丸岡南中は木刚中、小絹中、西の原中、桜台中に比べてかなり充実 しているといえる。学習ゾーンを設け専用の掲示スペースを確保し た効果と考えられる。

生活類のうち、「生活記録」「「学外情報」、「装飾」には運営方式・ 校舎タイプの差はないが、「標語」、「生活の決まり・お知らせ」、「給 食・保健・衛生情報」、「係・委員会等活動情報」、「学校案内」には 違いが認められる。「生活の決まり・お知らせ」、「給食・保健・衛 生情報」、「係・委員会等活動情報」については、至民中、丸岡南中 が木刈中、小絹中、西の原中、桜台中に比べて大幅に少ない。H B と学級教室の床面積、壁面積の差が、当該類型掲示量の差となって 表れた結果になっている。一方、「学校案内」については、至民中、 丸岡南中が木刈中、小絹中、西の原中に比べて多いことがわかる。 これは、至民中、丸岡南中の空間構成が比較的複雑であることから、 サイン計画が十分になされているためである。

学習類については、「教具」、「学習記録・作品（個人)」、「学習記 録・作品（集団）」共に、運営方式・校舎タイプによってはっきり とした違いが認められる。中でも「教具」は、至民中、丸岡南中が 木刈中、小絹中、西の原中よりも大幅に多いことがわかる。特別教 室型運営方式の学級教室に見られる「積極的な教材の掲示につなが らない」という課題に対しては、至民中、丸岡南中は十分に応えら れていると考えられる。「学習記録・作品 (集団)」の存在は、学習 活動における弾力的なグループ形成を示すものと考える（写真 4)。

\section{5. 教室まわりの配置場所別掲示量 \\ 5.1 配置場所別掲示量}

表 5 は、1 学級当たりの配置場所別掲示量を算出し、運営方式・ 校舎タイプで比較・検定したものである注8)。木刚中、小絹中、西 の原中は学級教室と廊下、桜台中は学級教室と O S 、至民中、丸岡 南中は教科教室およびO S かつH Bおよび共通スクエアに分けて整 理している。

木刈中、小絹中、西の原中では、掲示物は共通して学級教室前方 壁面、後方壁面、廊下側壁面、廊下教室側壁面に配置されていた。 壁面外掲示は確認されなかった。掲示量は、学級教室壁面掲示量が $10.58 \sim 16.65 \mathrm{~m}^{2}$ 、廊下壁面掲示量が $2.97 \sim 4.18 \mathrm{~m}^{2}$ となる。桜台 中では、掲示物のほとんどが学級教室前方壁面、後方壁面、O S 可 動間仕切壁面、O S と教室を隔てる収納棚に配置されていた。掲示 量は、学級教室壁面掲示量が $14.68 \mathrm{~m}^{2} 、 \mathrm{O} \mathrm{S}$ 壁面掲示量が $2.62 \mathrm{~m}^{2}$ 、 壁面外掲示量が $3.86 \mathrm{~m}^{2}$ などとなっている。

至民中では、H B 壁面、収納棚、教科教室前方壁面、後方壁面、 O S 教室側壁面（ホワイトボード壁）、可動間仕切壁面、ホワイト ボード、掲示板、天井、床のいたるところに配置されていた。掲示 量は、教科教室壁面掲示量が $10.07 \mathrm{~m}^{2} 、 \mathrm{H}$ B 壁面掲示量が $2.43 \mathrm{~m}^{2}$ 、 $\mathrm{H}$ B 壁面外掲示量が $2.44 \mathrm{~m}^{2} 、 \mathrm{O} \mathrm{S}$ 壁面掲示量が $6.72 \mathrm{~m}^{2} 、 \mathrm{O} \mathrm{S}$ 壁面 外掲示量が $4.20 \mathrm{~m}^{2}$ などとなっている。掲示物が分散配置されてい る要因として、1学級当たりの床面積が最も広く空壁が多いこと、 加えて壁面外の設定を豊富にしていることがあげられる。

丸岡南中では、H B 壁面、教科教室前方壁面、後方壁面、O S 可 動間仕切壁面など壁面を中心に配置されていた。壁面外掲示は教科 教室、O S の天井にわずかにあるのみだった。掲示量としては、教 
科教室壁面掲示量が $4.70 \mathrm{~m}^{2} 、 \mathrm{H}$ B 壁面掲示量が $8.33 \mathrm{~m}^{2} 、 \mathrm{O} \mathrm{S}$ 壁面 掲示量が $6.29 \mathrm{~m}^{2}$ などとなっている。1 学級当たりの床面積は至民 中に次ぐ広さとなるが、揭示物の配置はそれほど分散していない。
各学習ゾーンのO S にまとまった壁面（各 $30 \mathrm{~m}^{2}$ 前後）が用意され ているからと考えられる。

表 3 掲示物の類型

\begin{tabular}{|c|c|c|}
\hline \multicolumn{2}{|r|}{ 掲示類 } & 具体内容 \\
\hline \multirow{9}{*}{ 生 } & 標語 & $\begin{array}{l}\text { 学校教育目標、学年目標、クラス目標、今月 } \\
\text { の目標、校歌など }\end{array}$ \\
\hline & 生活の決まり・お知らせ & $\begin{array}{l}\text { 学校便り、学年便り、学級通信、時間割表、 } \\
\text { 校時表など }\end{array}$ \\
\hline & 給食·保健·衛生情報 & 献立表、食育通信、給食当番、保健便りなど \\
\hline & 係·委員会等活動情報 & $\begin{array}{l}\text { 学級組織図、週直、班活動、委員会活動、生 } \\
\text { 徒会だよりなど }\end{array}$ \\
\hline & 生活記録 & 生徒写真、表彰状、行事感想文など \\
\hline & 学外情報 & 高校入試案内、募金案内など \\
\hline & 装飾 & 絵画、写真、イラスト、飾りなど \\
\hline & 学校案内 & 校舎案内、避難経路図など \\
\hline & その他の生活類 & 上記項目に該当しない生活類 \\
\hline \multirow{3}{*}{$\begin{array}{l}\text { 学 } \\
\text { 習類 }\end{array}$} & 教具 & 学習計画表、教具 \\
\hline & 学習記録・作品（個人） & 個人の学習記録・作品 \\
\hline & 学習記録・作品 (集団) & グループによる学習記録・作品 \\
\hline
\end{tabular}

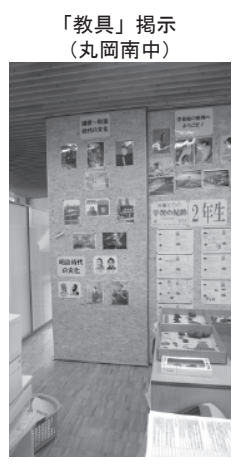

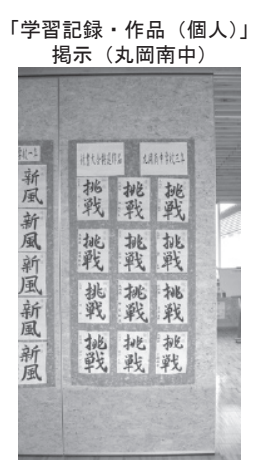

写真 4 学習類掲示例

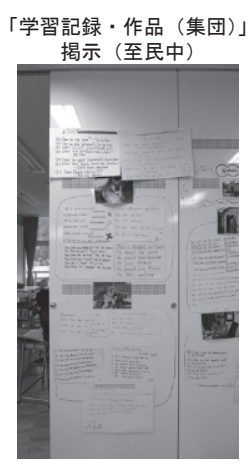

表 4 教室まわりの類型別掲示量（1学級当たり）結果および比較

\begin{tabular}{|c|c|c|c|c|c|c|c|c|c|c|c|c|c|c|c|c|}
\hline \multirow{2}{*}{\multicolumn{3}{|c|}{$\begin{array}{l}\text { 各校平均/全体平均/ } \\
\text { 運営方式·校舎夕イプ別平均 / } \\
\text { 比較検定 }\end{array}$}} & \multicolumn{10}{|c|}{ 生活類 $\left(\mathrm{m}^{2}\right)$} & \multicolumn{4}{|c|}{ 学習類 $\left(\mathrm{m}^{2}\right)$} \\
\hline & & & \multirow{2}{*}{$\begin{array}{l}\text { 㮒 } \\
\text { 語 } \\
2.10 \\
\end{array}$} & \multirow{2}{*}{ 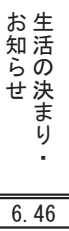 } & \multirow{2}{*}{$\begin{array}{l}\text { 衛給 } \\
\text { 懩 } \\
\text { 報保 } \\
\text { 健 } \\
\\
1.40\end{array}$} & \multirow{2}{*}{ 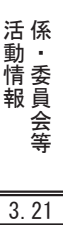 } & \multirow{2}{*}{$\begin{array}{l}\text { 生 } \\
\text { 話 } \\
\text { 録 } \\
\\
2.52 \\
\end{array}$} & \multirow{2}{*}{$\begin{array}{l}\text { 学 } \\
\text { 情 } \\
\text { 報 } \\
\\
0.09 \\
\end{array}$} & \multirow{2}{*}{$\begin{array}{l}\text { 装 } \\
\text { 飾 } \\
\\
0.66\end{array}$} & \multirow{2}{*}{$\begin{array}{l}\text { 学 } \\
\text { 榇 } \\
\text { 芮 } \\
0.15 \\
\end{array}$} & \multirow{2}{*}{$\begin{array}{l}z \\
\rho \\
\text { 他 } \\
\infty \\
\text { 生 } \\
\text { 活 } \\
\text { 類 } \\
0.01\end{array}$} & \multirow{2}{*}{$\begin{array}{l}\text { 弇 } \\
\text { 計 } \\
16.60\end{array}$} & \multirow{2}{*}{$\begin{array}{l}\text { 教 } \\
\text { 具 } \\
0.18\end{array}$} & \multirow{2}{*}{$\begin{array}{c}\text { 個舜 } \\
\text { 蛍 } \\
\text { 録 } \\
\text { 作 } \\
\text { 品 } \\
3.13\end{array}$} & \multirow{2}{*}{ 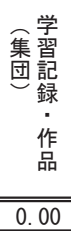 } & \multirow{2}{*}{$\begin{array}{l}\text { 畣 } \\
3.30\end{array}$} \\
\hline \multirow{4}{*}{$\begin{array}{l}\text { 特別 } \\
\text { 教室型 }\end{array}$} & & 木刘中 & & & & & & & & & & & & & & \\
\hline & \multirow{2}{*}{$\begin{array}{l}\text { 片廊下 } \\
\text { タイプ }\end{array}$} & $\begin{array}{l}\text { 小絹中 } \\
\end{array}$ & 0.63 & 3.49 & 1.16 & 1.66 & 3.93 & 0.53 & 0.28 & 0.02 & 0.00 & 11.70 & 0.63 & 1.22 & 0.00 & 1.85 \\
\hline & & 西の原中 & 2.14 & 3.37 & 1.16 & 3.05 & 2.72 & 2.61 & 0.87 & 0.36 & 0.04 & 16.33 & 0.15 & 2.13 & 0.00 & 2.28 \\
\hline & \multirow{3}{*}{$\begin{array}{l}\text { OS } \\
\text { タイプ }\end{array}$} & 桜台中 & 3.37 & 5.43 & 1.52 & 2.48 & 4.74 & 0.96 & 0.73 & 0.30 & 0.08 & 19.62 & 1.60 & 0.00 & 0.00 & 1.60 \\
\hline \multirow{2}{*}{$\begin{array}{l}\text { 教科 } \\
\text { 教室型 } \\
\end{array}$} & & 至民中 & 2.26 & 1.21 & 0.78 & 1.22 & 0.84 & 0.84 & 0.16 & 0.40 & 0.00 & 7.71 & 9.52 & 7.43 & 3.10 & 20.05 \\
\hline & & 丸岡南中 & 1.62 & 1.50 & 0.54 & 0.19 & 4.88 & 0.35 & 0.51 & 0.84 & 0.00 & 10.44 & 7.45 & 3.10 & 0.85 & 11.41 \\
\hline \multicolumn{3}{|c|}{$\begin{array}{ll}\text { 全体平均 } \\
\end{array}$} & 2.02 & $\begin{array}{ll}3.58 \\
\end{array}$ & 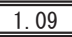 & 1.97 & (3.27 & 0.90 & 0.54 & 0.35 & 0.02 & $\begin{array}{l}13.73 \\
\end{array}$ & $\begin{array}{l}.25 \\
\end{array}$ & 2.83 & $\begin{array}{ll}0.66 \\
\end{array}$ & $\begin{array}{l}6.75 \\
\end{array}$ \\
\hline \multirow{2}{*}{\multicolumn{3}{|c|}{$\begin{array}{l}\text { (1)特別教室型・片廊下タイプ平均 } \\
\text { (2)特別教室型・Oタプ平均 }\end{array}$}} & 1.63 & 4.44 & 1.24 & 2.64 & 3.06 & 1.08 & 0.60 & 0.18 & 0.02 & $\begin{array}{lll}14.88 \\
\end{array}$ & 0.32 & 2.16 & 0.00 & 2.48 \\
\hline & & & 3.37 & 5.43 & 1.52 & 2.48 & 4.74 & 0.96 & 0.73 & 0.30 & 0.08 & 19.62 & 1.60 & 0.00 & 0.00 & 1.60 \\
\hline \multicolumn{3}{|c|}{ (3)教科教室型・OSタイプ平均 } & 1.94 & 1.36 & 0.66 & 0.70 & 2.86 & 0.60 & 0.34 & 0.62 & 0.00 & 9.07 & 8.49 & 5.27 & 1.98 & 15.73 \\
\hline \multicolumn{3}{|c|}{$\begin{array}{c}\text { 一元配置分散分析検定 } \\
* *: 1 \% \text { 有意 } * \text { 意 }\end{array}$} & * & ** & ** & ** & & & & * & & ** & ** & ** & ** & ** \\
\hline \multicolumn{17}{|c|}{ 多重比較（Tukey-Kramer法） } \\
\hline \multirow{2}{*}{\multicolumn{3}{|c|}{$\frac{(1)-(2)}{(1)-(3)}$}} & * & & & & & & & & $\infty$ & & & & & \\
\hline & & & & ** & ** & ** & & & & * & $\infty$ & ** & ** & * & ** & ** \\
\hline \multicolumn{3}{|c|}{ (2) -3} & & ** & ** & * & & & & & 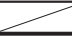 & $* *$ & ** & ** & ** & ** \\
\hline
\end{tabular}

表 5 教室まわりの配置場所別掲示量 ( 1 学級当たり) 結果および比較

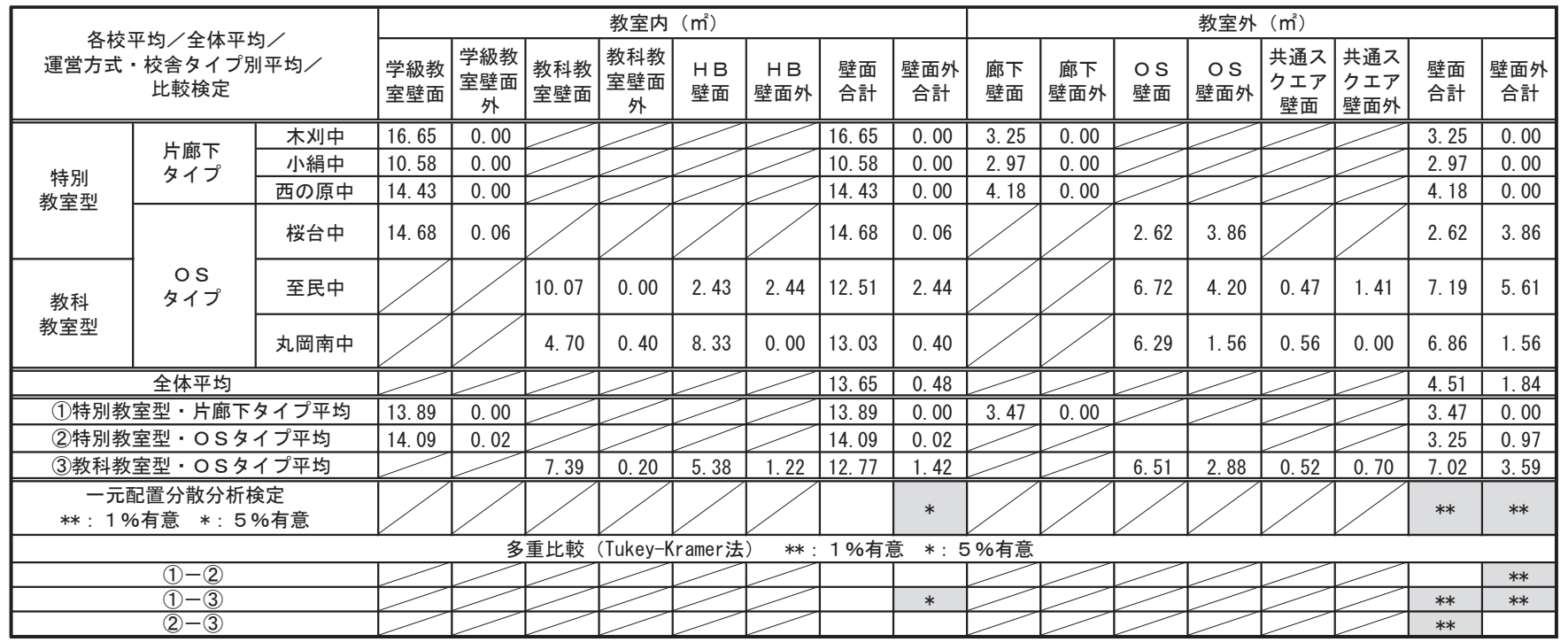

※括弧は、可動間仕切壁に限定した場合の壁面掲示量を示す。 

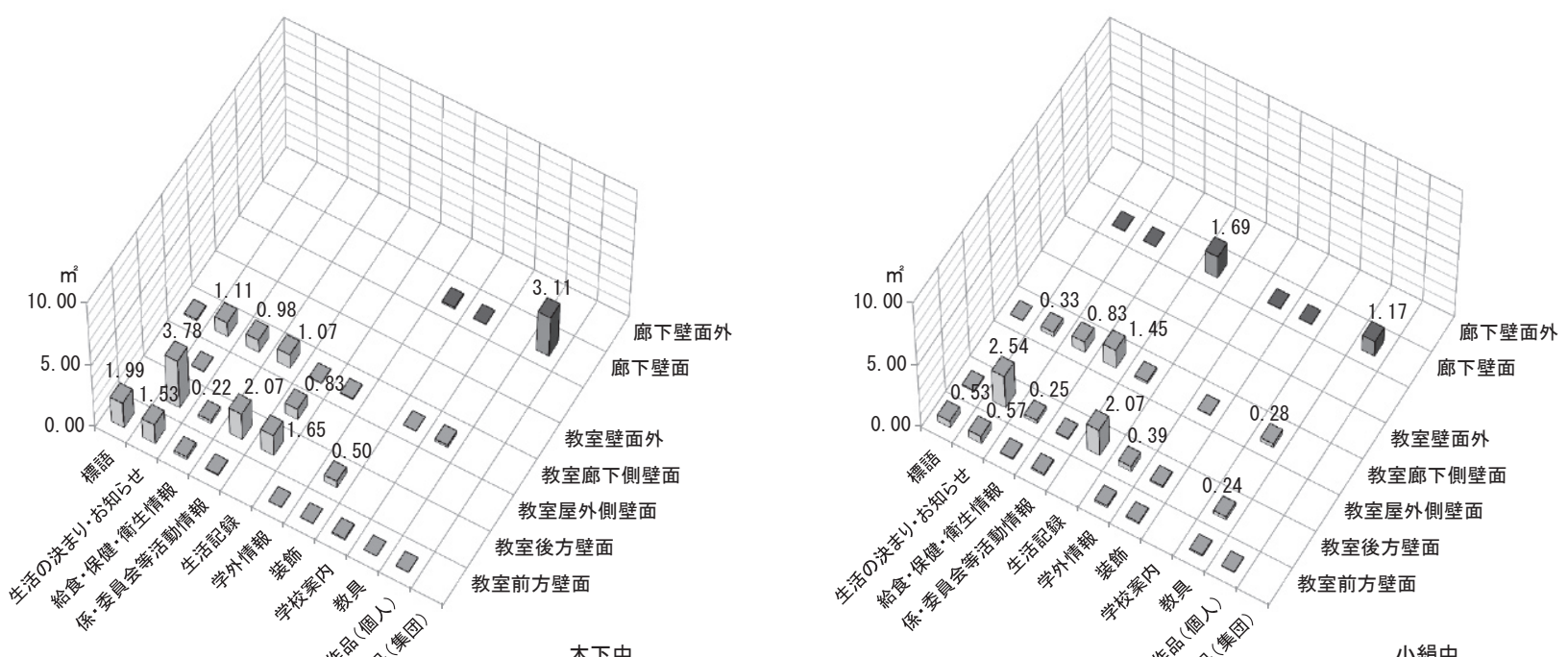
特別教室型・片廊下タイプ
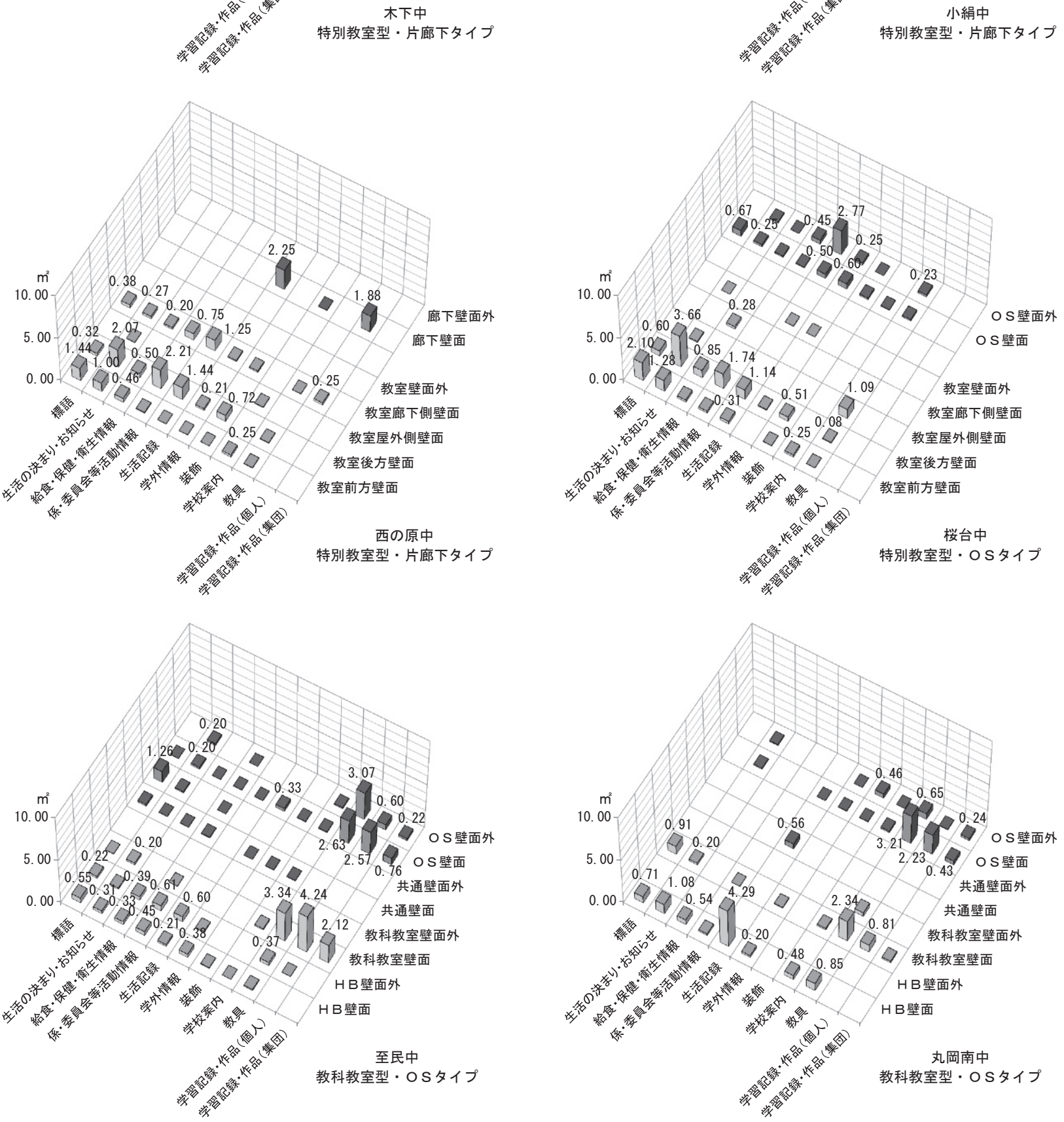

図4 配置場所別・類型別掲示量（1学級当たり）結果 


\section{2 配置場所別・類型別揭示量}

図 4 は、 1 学級当たりの配置場所別・類型別掲示量を、学校ごと に表したものである。以下に類型ごとに配置状況を見る。

「標語」は、木刈中、小絹中、西の原中、桜台中では多くが教室 前方壁面に掲示されていた。至民中では共通スクエア壁面外を中心 に配置されていた。丸岡南中では教科教室壁面、HB壁面に掲示さ れていた。「生活の決まり・お知らせ」は、木刈中、小絹中、西の 原中、桜台中では教室後方壁面を中心に掲示されていた。至民中で は生活・学習ゾーンの壁面・壁面外に分散配置されていた。丸岡南 中ではH B を中心に配置されていた。「給食·保健·衛生情報」、「係・ 委員会等活動情報」は、木刈中、小絹中、西の原中では教室後方壁 面、廊下側壁面、桜台中では教室後方壁面を中心に掲示されていた。 至民中では生活・学習ゾーンの壁面・壁面外に分散配置されていた。 丸岡南中ではH B を中心に配置されていた。「生活記録」は、木刈中、 小絹中、西の原中では教室後方壁面を中心に配置されていた。桜台 中ではOS壁面外（教室とOS を隔てる収納棚）を中心に掲示され ていた。掲示は、そのほとんどが生徒 1 人 1 人の生活記録によるも のである (写真 5 左上)。丸岡南中ではH B 壁面を中心に掲示され ていた。これらはクラスの集合写真や行事感想文等によるものであ る (写真 5 右上)。「学外情報」は、西の原中の廊下壁面で突出して 多いが、その多くが第 3 学年廊下壁面の高校入試案内掲示によるも のである (写真 5 左下)。

「教具」は、木刚中、小絹中、西の原中、桜台中ではほとんど見 られなかった。桜台中第 3 学年の教室屋外側壁面で詩歌の掲示が確 認できる程度だった（写真 5 右下）。至民中では教科教室壁面、O S 壁面外、O S 壁面を中心に配置されていた。丸岡南中ではO S 壁 面、教科教室壁面を中心に配置されていた。「学習記録・作品」は、 木刈中、小絹中、西の原中では廊下壁面に掲示されていた。桜台中 では掲示が確認できなかった。至民中では教科教室壁面、O S 壁面 を中心に掲示されていた。丸岡南中ではO S 壁面を中心に配置され ていた。

桜台中は、木刚中、小絹中、西の原中と掲示物の配置状況が似て いる。桜台中のＯS は、掲示上、学級教室の延長として機能してい るといえる。至民中、丸岡南中では、H B 、共通スクエアが主に生 活類を掲示寸る空間として、また教科教室、OS は主に学習類を掲 示する空間として機能しているといえる。

\section{6. 教室まわりの掲示手段別掲示量}

表 6 は、1 1 学級当たりの掲示手段別掲示量を掲示面構造ごとに表 したものである。掲示手段別掲示量で最も多かったのは木質壁・家 具や掲示板を中心に画鋲でとめるケースで、計 14.32 mだった。テ

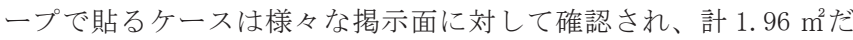
った。その他、黒板やホワイトボード壁・家具を中心に直書き（+ a) するケース注 9$)$ が $1.60 \mathrm{~m}^{2}$ 、磁石でとめるケースが $1.25 \mathrm{~m}^{2}$ 、掲 示板を中心にフック付きネジを設けつり下げるケースが $0.47 \mathrm{~m}^{2}$ と なっている。

表 7 は、1 学級当たりの掲示手段別掲示量を算出し、運営方式・ 校舎タイプで比較・検定したものである注 10)。掲示手段のうち、画鋲、 テープ、磁石、フック付きネジ、備え付けプレート主11) は全事例で 確認されている。その中でテープ、磁石には、運営方式・校舎タイ プによって違いが認められる。テープは、至民中、丸岡南中が木刈 中、小絹中、西の原中より多い。O S にコンクリート壁や空壁が多 いためと考えられる。ただし、ガラス戸・窻への掲示には採光や見 通し上、問題もある（写真 6 )。磁石もテープと同様、至民中、丸 岡南中が木刈中、小絹中、西の原中より多い。中でも至民中が突出 している。OSで壁の一部をホワイトボード仕様にし加えてO S を 中心に掲示板やホワイトボードを置いていたためと考えられる。備 え付けプレートは、至民中、丸岡南中が多い。校舎の空間構成が比 較的複雑であることから、サイン計画が十分になされているためと 考えられる。

至民中、丸岡南中では、揭示スペースを確保するための様々な工 夫が確認された。設計者の工夫として、たとえば丸岡南中ではO S
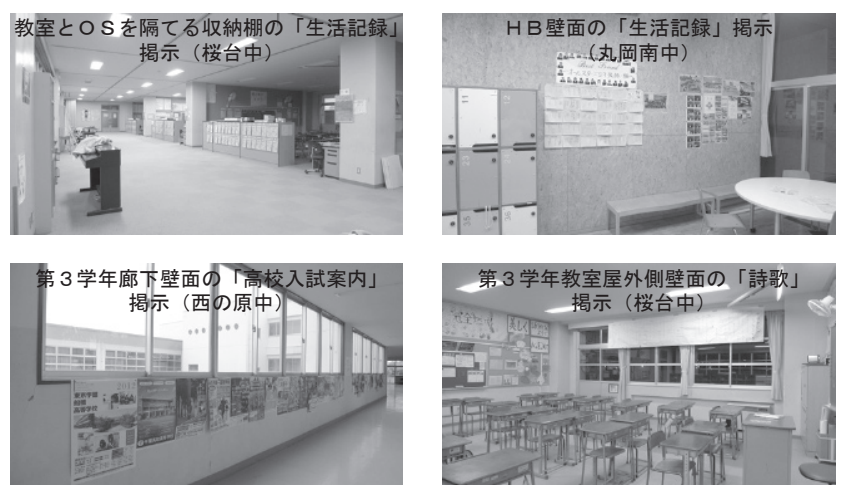

写真 5 特徴的掲示配置例

表 6 掲示面構造ごとの掲示面別掲示量（1学級当たり）結果

\begin{tabular}{|c|c|c|c|c|c|c|c|c|c|c|c|c|c|c|c|}
\hline $\begin{array}{c}\text { 揭 } \\
\text { 靕 } \\
\text { 段 }\end{array}$ & 鋲 & $\begin{array}{l}\bar{T} \\
\text { I }\end{array}$ & $\begin{array}{l}\text { 干直畫 } \\
\alpha\end{array}$ & 磁 & $\begin{array}{c}\text { ネフ } \\
\text { 济少 } \\
\text { 恷 } \\
\text { き }\end{array}$ & $\begin{array}{l}\text { プ備 } \\
\text { 糹 } \\
\text { 卜付 }\end{array}$ & 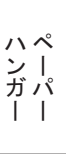 & 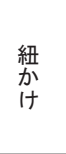 & 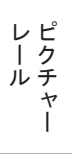 & $\begin{array}{l}\frac{\dot{亠}}{\tau} \\
\text { 掛 } \\
\text { け }\end{array}$ & 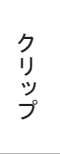 & 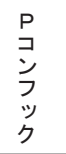 & $\begin{array}{l}\text { フ } \\
\text { 尝 } \\
\text { シ } \\
1 \\
\text { ル }\end{array}$ & 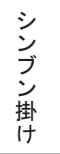 & $\begin{array}{l}\text { 揭 } \\
\text { 面 } \\
\text { 翼 } \\
\text { 計 }\end{array}$ \\
\hline 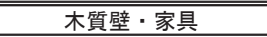 & $\overline{7.82}$ & 0.61 & & & 0.02 & 0.28 & & 0.00 & & 0.01 & & & & & 8.74 \\
\hline 掲示板 & 6.13 & 0.00 & & 0.02 & 0.19 & & & 0.00 & & 0.02 & & & & & 6.36 \\
\hline ホワイトボード壁・家具 & & 0.17 & 0.51 & 0.91 & & 0.00 & & & & & & & & & 1.59 \\
\hline 黒板 & 0.01 & 0.00 & 1.09 & 0.24 & & & & & & & & & & & 1.34 \\
\hline コンクリート壁 & & 0.63 & & & 0.25 & 0.03 & 0.20 & 0.05 & & 0.00 & & 0.04 & 0.03 & & 1.24 \\
\hline 木質ルーバー天井 & 0.36 & 0.03 & & & 0.01 & & & 0.00 & 0.07 & & 0.05 & & & & 0.52 \\
\hline ガラス戸・言 & & 0.44 & & & & 0.00 & & 0.00 & & 0.03 & & & & & 0.48 \\
\hline スチル扉・家具 & 0.00 & 0.04 & & 0.08 & & & & & & & & & & & 0.12 \\
\hline その他 & & & & & 0.02 & & & 0.04 & & & & & & 0.01 & 0.07 \\
\hline フローリング床 & & 0.02 & & & & & & & & & & & & & 0.02 \\
\hline 揭示手段別累計 & 14.32 & $\overline{1.96}$ & 1.60 & 1.25 & 0.47 & 0.32 & 0.20 & 0.10 & 0.07 & 0.06 & 0.05 & 0.04 & 0.03 & 0.01 & $\overline{20.48}$ \\
\hline
\end{tabular}


表 7 教室まわりの掲示手段別掲示量（1学級当たり）結果および比較

\begin{tabular}{|c|c|c|c|c|c|c|c|c|c|c|c|c|c|c|c|c|}
\hline \multicolumn{3}{|c|}{$\begin{array}{c}\text { 各校平均/全体平均/ } \\
\text { 運営方式·校舎タイプ別平均 } \\
\text { /比較検定 }\end{array}$} & $\begin{array}{l}\text { 画 } \\
\text { 鋲 }\end{array}$ & $\begin{array}{l}\bar{T} \\
\text { I }\end{array}$ & $\begin{array}{l}\text { 干直畫 } \\
\alpha\end{array}$ & 磁 & $\begin{array}{c}\text { ネフ } \\
\text { ジッ } \\
\text { ク } \\
\text { 恷 } \\
\text { き }\end{array}$ & $\begin{array}{l}\text { プ備 } \\
\text { 离 } \\
\text { ト恷 }\end{array}$ & 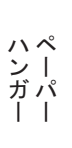 & $\begin{array}{l}\text { 紐 } \\
\text { 十 } \\
\text { け }\end{array}$ & 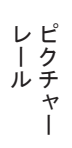 & 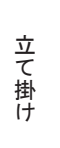 & $\begin{array}{l}ク \\
\text { I } \\
\text { プ } \\
\text { プ }\end{array}$ & 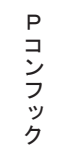 & 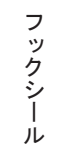 & 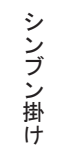 \\
\hline \multirow{4}{*}{ 特別 } & \multirow{3}{*}{$\begin{array}{l}\text { 片廊下 } \\
\text { タイプ }\end{array}$} & 木刈中 & 15.64 & 1.38 & 2.68 & 0.07 & 0.07 & 0.02 & 0.00 & 0.02 & 0.00 & 0.02 & 0.00 & 0.00 & 0.00 & 0.00 \\
\hline & & 小絹中 & 11.17 & 0.15 & 1.26 & 0.61 & 0.22 & 0.02 & 0.00 & 0.00 & 0.00 & 0.12 & 0.00 & 0.00 & 0.00 & 0.00 \\
\hline & & 西の原中 & 15.06 & 0.70 & 1.35 & 0.47 & 0.98 & 0.04 & 0.00 & 0.00 & 0.00 & 0.01 & 0.00 & 0.00 & 0.00 & 0.00 \\
\hline & \multirow{3}{*}{$\begin{array}{l}\text { OS } \\
\text { タイプ }\end{array}$} & 桜台中 & 14.92 & 2.97 & 1.26 & 1.21 & 0.70 & 0.07 & 0.00 & 0.09 & 0.00 & 0.01 & 0.00 & 0.00 & 0.00 & 0.00 \\
\hline \multirow{2}{*}{$\begin{array}{l}\text { 教科 } \\
\text { 教室型 } \\
\end{array}$} & & 至民中 & 11.42 & 4.40 & 3.07 & 4.38 & 0.86 & 1.52 & 1.19 & 0.25 & 0.42 & 0.19 & 0.00 & 0.00 & 0.01 & 0.06 \\
\hline & & 丸岡南中 & 17.68 & 2.17 & 0.00 & 0.77 & 0.02 & 0.26 & 0.00 & 0.22 & 0.00 & 0.00 & 0.29 & 0.25 & 0.19 & 0.00 \\
\hline \multicolumn{3}{|c|}{$\begin{array}{ll}\text { 全体平均 } \\
\end{array}$} & 14.32 & 1.96 & 1.60 & 1.25 & 0.47 & 0.32 & 0.20 & 0.10 & 0.07 & 0.06 & 0.05 & 0.04 & 0.03 & 0.01 \\
\hline \multirow{2}{*}{\multicolumn{3}{|c|}{$\begin{array}{l}\text { (1)特別教室型・片廊下タイプ平均 } \\
\text { (2)特別教室型・OSタプ平均 }\end{array}$}} & 13.96 & 0.74 & 1.76 & 0.39 & 0.42 & 0.03 & 0.00 & 0.01 & 0.00 & 0.05 & 0.00 & 0.00 & 0.00 & 0.00 \\
\hline & & & 14.20 & 1.30 & 1.64 & 0.59 & 0.49 & 0.04 & 0.00 & 0.03 & 0.00 & 0.04 & 0.00 & 0.00 & 0.00 & 0.00 \\
\hline \multicolumn{3}{|c|}{ (3)教科教室型・OSタイプ平均 } & 14.55 & 3. 28 & 1.53 & 2.58 & 0.44 & 0.89 & 0.60 & 0.23 & 0.21 & 0.09 & 0.14 & 0.13 & 0.10 & 0.03 \\
\hline \multicolumn{3}{|c|}{$\begin{array}{c}\text { 一元配置分散分析検定 } \\
* *: 1 \% \text { 意 } \quad *: 5 \% \text { 有意 }\end{array}$} & & $*$ & & * & & ** & & ** & & & & & & \\
\hline \multicolumn{17}{|c|}{ 多重比較 (Tukey-Kramer法) } \\
\hline \multirow{2}{*}{\multicolumn{3}{|c|}{$\frac{(1)-(2)}{(1-(3)}$}} & & & & & & * & 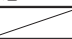 & & $\infty$ & & 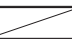 & $\infty$ & $\infty$ & $\infty$ \\
\hline & & & & * & & ** & & $* *$ & $\infty$ & ** & $\infty$ & & $=$ & $\infty$ & $\infty$ & $\infty$ \\
\hline \multicolumn{3}{|c|}{ (2)-(3) } & & & & & & * & $=$ & * & $m$ & & $\infty$ & $m$ & $\infty$ & $=$ \\
\hline
\end{tabular}

に可動間仕切壁（理科O S のみ掲示機能を高めた固定間仕切壁）を 設定していた（写真 7 左）。至民中ではO S 、教室の壁を一部ホワ イトボード仕様にしていた（写真 7 中）。HBには正面背面掲示可 能な収納家具を設置していた（写真8左上）。使い手の工夫として、 たとえば至民中ではＯS のコンクリート打ち放し壁面にペーパーハ ンガーを取り付けていた（写真 7 右）。O S を中心に掲示板やホワ イトボードを置いていた（写真 8 右上)。フローリング床面を掲示 に利用していた（写真 8 右下）。丸岡南中ではO S、教室の木質ル

\section{ーバー天井面を掲示に利用していた（写真 8 左下）。}

至民中、丸岡南中は共に、採光を確保し見通しを良くする上で、 掲示に向かない空壁を多用している。掲示スペースを確保するため、 至民中は一部壁面の仕様を変えたり壁面外の設定を増やしたりして いるといえる、また丸岡南中は計画的に可動間仕切壁（固定間仕切 壁）を設けているといえる。

\section{7. 総括}

\section{1 まとめ}

本報では、中学校における教室まわりの情報伝達手段としての掲 示空間のあり方について建築計画的知見を得ることを目的とし、教 科教室型・OSタイプ事例 2 校を含む中学校 6 校を対象に、あわせ て 18 学級分の教室まわりの床面積、壁面積、掲示物の量・内容・配置・ 掲示手段・掲示面構造について実測、運営方式・校舎タイプによる 比較分析を行った。その結果、以下の知見が得られた。

1 ）教室まわりの掲示量・壁面掲示率・単位床面積当たり総掲示量 の分析から、次のことがわかった。(1)床面積に対する壁面積の 割合は、木刚中、小絹中、西の原中の約 1.7 に対して、桜台中が 約 1.0 、至民中、丸岡南中が約 1.2 、約 1.5 となる。至民中は桜 台中と同等、壁が疎に設定されているといえる。一方、丸岡南 中は木刈中、小絹中、西の原中と同等、壁が密に設定されてい るといえる。(2)教室まわりの壁面掲示量は運営方式・校舎タイ プの差がほとんどなくいずれも全体平均 $18.09 \mathrm{~m}^{2}$ に近い值であ るが、壁面外掲示量を加えた総掲示量は木刈中、小絹中、西の原 中が $13.55 \sim 19.90 \mathrm{~m}^{2}$ 、桜台中が $21.22 \mathrm{~m}^{2}$ 、至民中、丸岡南中 が $27.76 \mathrm{~m}^{2} 、 21.85 \mathrm{~m}^{2}$ となる。比較的壁が疎に設定される桜台中、
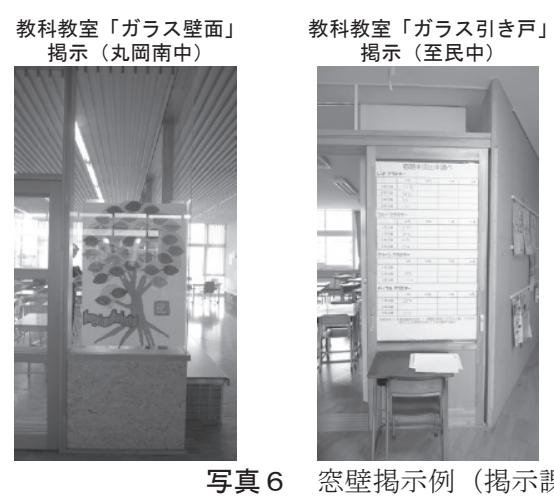

OS「ガラス空」掲示
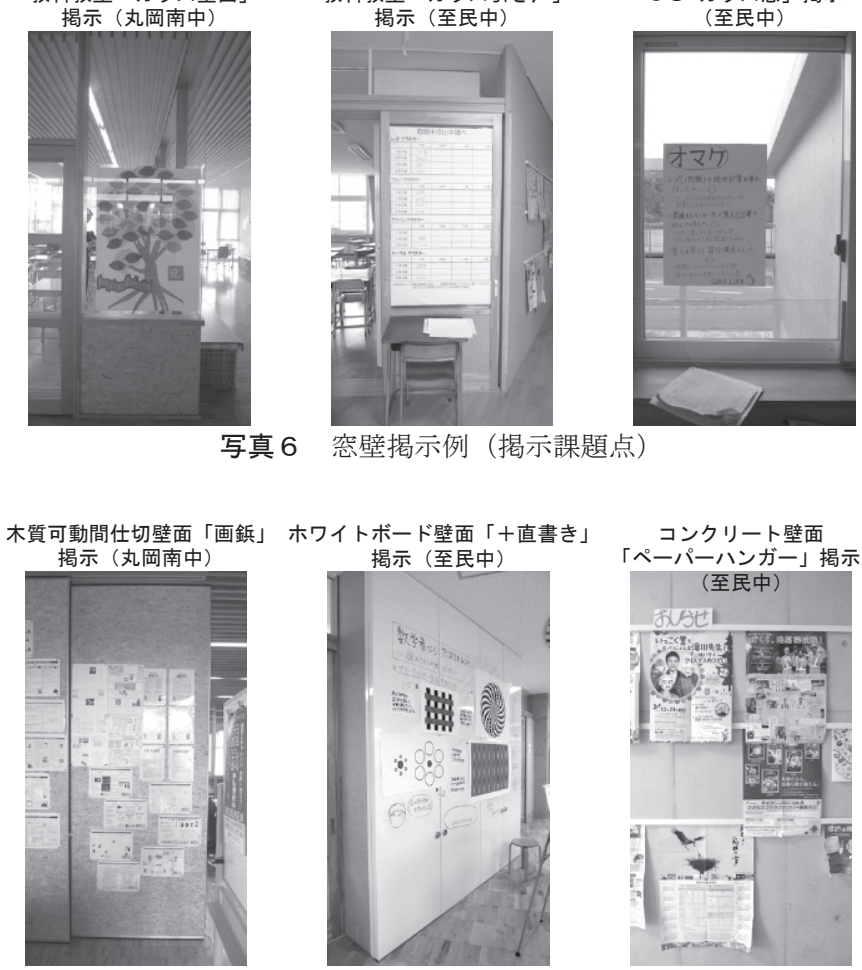

写真 7

至民中・丸岡南中の壁面掲示工夫例
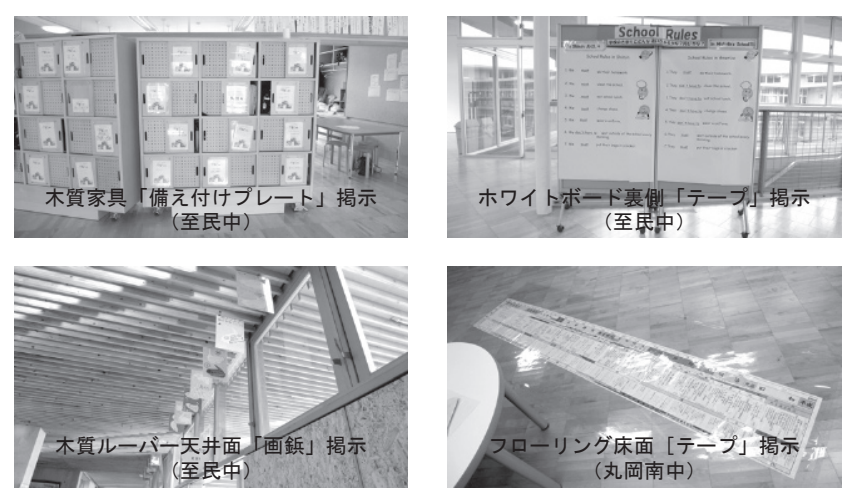

写真 8 至民中・丸岡南中の壁面外掲示工夫例 
至民中では、壁面外掲示を充実させているといえる。(3)至民中、 丸岡南中における各教科学習ゾーンの 1 学級当たりの総掲示量 を比較すると、国語、数学、理科は至民中の方が多く、英語、社 会は丸岡南中の方が多い。2 事例を見る限り、教科の性質による 掲示要求の差はないと考える。(4)壁面掲示率は、至民中、丸岡南 中が比較的小さい。O S、教科教室で掲示に向かない空壁が多い ことが影響していると考えられる。(5)至民中、丸岡南中は、単位 床面積当たり総掲示量としては小さいものの、床面積が広い分、 掲示量が増しているといえる。床面積の広さに応じて、掲示要求 も増すと考えられる。

2) 教室まわりの類型別掲示量の分析から、次のことがわかった。 (1)掲示内容は、生活類として「標語」、生活の決まり・お知らせ」、 「給食・保健・衛生情報」、「係・委員会等活動情報」、「生活記録」、 「学外情報」、「装飾」、「学校案内」、「その他の生活類」の 9 項目、 学習類として、「教具」、「学習記録・作品 (個人)」、「学習記録・ 作品（集団）」の 3 項目に分類できる。(2)生活類合計は、木刈中、 小絹中、西の原中が $11.70 \sim 16.60 \mathrm{~m}^{2}$ 、桜台中が $19.62 \mathrm{~m}^{2}$ 、至民中、

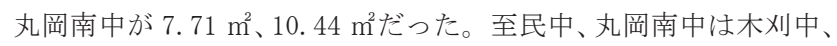
小絹中、西の原中、桜台中に比べて少ない。H B の床面積、壁面 積が木刚中、小絹中、西の原中、桜台中の学級教室（掲示の大 半を生活類掲示が占める) より狭く小さいことが影響している。 一方、学習類合計は、木刚中、小絹中、西の原中が $1.85 \sim 3.30 \mathrm{~m}^{2}$ 、 桜台中が $1.60 \mathrm{~m}^{2}$ 、至民中、丸岡南中が $20.05 \mathrm{~m}^{2} 、 11.41 \mathrm{~m}^{2}$ だった。 至民中、丸岡南中は木刈中、小絹中、西の原中に比べてかなり充 実しているといえる。学習ゾーンを設け専用の掲示スペースを確 保した効果と考えられる。「学習記録・作品（集団）」の存在は、 学習活動における弾力的なグループ形成を示すものと考える。

3）至民中では、H B 壁面、収納棚、教科教室前方壁面、後方壁面、 O S 教室側壁面（ホワイトボード壁）、可動間仕切壁面、ホワイ トボード、掲示板、天井、床のいたるところに配置されていた。 掲示物が分散配置されている要因として、1学級当たりの床面積 が最も広く空壁が多いこと、加えて壁面外の設定を豊富にしてい ることがあげられる。丸岡南中では、H B 壁面、教科教室前方壁 面、後方壁面、O S 可動間仕切壁面など壁面を中心に配置されて いた。壁面外掲示は教科教室、O S の天井にわずかにあるのみだ った。1 学級当たりの床面積は至民中に次ぐ広さとなるが、掲示 物の配置はそれほど分散していない。各学習ゾーンのOSにまと まった壁面（各 $30 \mathrm{~m}^{2}$ 前後）が用意されているからと考えられる。 (2)桜台中は、木刈中、小絹中、西の原中と掲示物の配置状況が似 ている。桜台中のＯSは、掲示上、学級教室の延長として機能し ているといえる。至民中、丸岡南中では、H B 、共通スクエアが 主に生活類を掲示する空間として、また教科教室、O S は主に学 習類を掲示する空間として機能しているといえる。

4）教室まわりの掲示手段別掲示量の分析から、次のことがわかっ た。(1掲示手段として、画鋲でとめるをはじめ、テープで貼る、 直書き $(+\alpha)$ する、磁石でとめる、フック付きネジでつり下げ るなどが確認された。(2)至民中、丸岡南中では、掲示面を確保す るための様々な工夫が確認された。設計者の工夫として、丸岡南 中ではＯSに可動間仕切壁を設定していた。至民中ではO S、教 室の壁を一部ホワイトボード仕様にしていた。H B には正面背面
掲示可能な収納家具を設置していた。使い手の工夫として、たと えば至民中ではＯS のコンクリート打ち放し壁面にペーパーハ ンガーを取り付けていた。OSを中心に掲示板やホワイトボード を置いていた。フローリング床面を掲示に利用していた。丸岡南 中ではO S、教室の木質ルーバー天井面を掲示に利用していた。 至民中、丸岡南中は共に、採光を確保し見通しを良くする上で、 掲示に向かない空壁を多用している。掲示スペースを確保するた め、至民中は一部壁面の仕様を変えたり壁面外の設定を増やした りしているといえる、また丸岡南中は計画的に可動間仕切壁（固 定間仕切壁）を設けているといえる。

\section{2 今後の課題}

本報では、運営方式・校舎タイプにより掲示空間利用を比較する ことで、中学校における掲示空間の検討を行った。前報では、校舎 タイプにより掲示空間利用を比較することで、小学校における掲示 空間の検討を行っている。今後は、小学校と中学校の学級担任制と 教科担任制の違いによる比較検討を行いたいと考える。また、掲示 空間の質的充実をふまえたO S 導入のあり方についても明らかにし ていきたい。

\section{謝辞}

本研究は、調查対象校として千葉県印西市立木刚中学校、茨城県 つぐみらい市立小絹中学校、千葉県白井市立桜台中学校、福井県 福井市立至民中学校、千葉県印西市立西の原中学校、福井県坂井市 立丸岡南中学校、調查協力者として刈屋信宏さん（2010 年度当時、 東京電機大学情報環境学部 4 年生)、近藤佑二さん（2011 年度当時、 東京電機大学情報環境学部 4 年生)のご協力のもとに行われました。 ここに感謝の意を表します。

\section{注}

注 1) データは調査当時のものである。

注 2) 前編では、小学校 10 校の学級担任を受けもつ教師 106 人に対するアンケ 一トの結果について報告している ${ }^{18)}$ 。アンケートでは、年間総掲示量の推 移について尋ねているが、6月、11月の総掲示量は共に充実し大きな差が 見られない回答結果を得ている。中学校の場合も同様と推測される。

注 3) 事例によって校舎規模、空間構成、学級数が異なるため、得られた 1 次 データをそのまま運営方式・校舎タイプで比較することはできない。そこ で比較できるよう「1学級当たり」を割り出し基準化した。(1)木刚中、小 絹中、西の原中（特別教室型・片廊下タイプ）では、実測した学級教室 1 室および接続廊下部分を対象学級のみが利用する。したがって、たとえば 1 学級当たりの床面積を求める場合、「学級教室」実測床面積十「廊下接続 部分」実測床面積を算出することになる。(2)桜台中 (特別教室型・O S タイプ) では、実測した学級教室 1 室を対象学級のみが利用し、OSをその学年全 体が利用する。したがって 1 学級当たりの床面積は、「学級教室」実測床面 積 $+\lceil\mathrm{OS} 」$ 実測床面積/学年学級数となる。(3)至民中、丸岡南中 (教科 教室型・O S タイプ）では、実測したH B を対象学級が、共通スクエアを そのユニット学級が、教科教室を全校学級のいくつか（全校学級数／教科 教室数）が、O S を全校学級が利用する。したがって 1 学級当たりの床面 積は、「HB」実測床面積十「共通スクエア」実測床面積/ユニット学級数 +「教科教室」実測床面積 $/$ 全校学級数 $\times$ 教科教室数 (英国数理社 5 教科分) 十「メディアセンター的 OS」実測床面積/全校学級数（英国数理社 5 教 科分）となる。

注 4）比較検定には一元配置分散分析および多重比較（Tukey-Kramer 法）を用 いた。バートレット検定およびルビーン検定から 3 群の等分散性を検定の 上、一元配置分散分析から 3 群の差を検定、さらに多重比較 (Tukey-Kramer 法）から群間の差の検定を行った。解析には「エクセル統計 2012」（社会情 報サービス）を使用した。 
注 5) 図にプロットされた記号について、アルファベット部分「KI」は木刈中、 $\lceil\mathrm{K} 0 」$ は小絹中、「NI」は西の原中、「SA」は桜台中、「SI」は至民中、「MA」 は丸岡南中を示す。語尾の数字は学年を表す。たとえば「KI1」は木刈中 1 年である。

注 6) 注 5) に同じ。

注 7) 注 4) に同じ。

注 8) 注 4) に同じ。

注 9）「直書き $(+\alpha) 」$ は、写真 7 中に示寸ように、黒板やホワイトボード壁・ 家具などにチョークやペンで直接書き示したものを指す。この場合、掲示 物が共に貼られているケースが多く、貼られている当該掲示物の量は「直 書き $(+\alpha) 」$ の部としてカウントしている。

注 10) 注 4) に同じ。

注 11)「備え付けプレート」は、写真8 左上に示すように、あらかじめ備え付 けられたプレートに入れて揭示する手段を意味する。

\section{参考文献}

1）長澤悟：子どもが主体的に学べる中学校とは，新建築，2006 年 10 月号, pp. 108-111，2006. 10

2）吉武泰水：教室廻りの設計方針，日本建築学会研究報告，第 17 号, pp. 501-504, 1952.3

3）青木正夫: 小学校の学級教室について, 日本建築学会論文報告集, 第 54 号, pp. 617-620, 1956. 10

4）長澤悟：いまなぜ学校か一学校建築の現状と未来, 建築䧴誌, vol. 107, No. 1326 , pp. 14-17, 1992.4

5）有田壮志，宮本文人：小学校の普通教室における揭示場所とその特性，日 本建築学会大会学術講演梗概集 $\quad$ - -1 分冊, pp. 23-24, 2004.8

6）金鍾石，宮本文人，有田壮志：小学校の普通教室における前・横・後の壁 面構成と揭示状況 小学校の普通教室における掲示場所計画に関する研 究 その 1, 日本建築学会大会学術講演梗概集 E-1 分冊, pp. 267-268, 2006. 9

7）有田壮志，宮本文人，金鍾石：小学校の普通教室における前・後の壁面の 掲示物とその特性 小学校の普通教室における掲示場所計画に関する研 究 その 2 , 日本建築学会大会学術講演梗概集 E-1 分冊, pp. 269-270, 2006. 9

8）山家達，八木澤壮一, 吉村彰 : 小学校における掲示およびそのスペースに
ついて一情報伝達手段からみた学校建築計画に関する研究, 日本建築学会 大会学術講演梗概集 E 分冊, pp. 475-476， 1993.9

9）山家達，八木澤壮一，吉村彰：小学校における掲示およびそのスペースに ついて一情報伝達手段からみた学校建築計画に関する研究 その 2 , 日本 建築学会大会学術講演梗概集 E 分冊, pp. 431-432, 1994.9

10）吉村彰 : 教育の現代化に伴う小学校の情報伝達手段としての掲示・展示空 間に関寸る研究，東京電機大学総合研究所年報、pp. 215-220、1995. 5

11）山家達，八木澤壮一，吉村彰：小学校における教師の掲示に対する意識に ついて一情報伝達手段からみた学校建築計画に関寸る研究 その 3 , 日本 建築学会大会学術講演梗概集 E-1 分冊, pp. 263-264, 1995.9

12）吉村彰、八木澤壮一、山家達 : 小学校における教育の現代化に伴う揭示空 間について一情報伝達手段からみた学校建築計画に関する研究 その 4 , 日本建築学会大会学術講演梗概集 E-1 分冊, pp. 265-266, 1995.9

13）斎藤潔，八木澤壮一，吉村彰：小・中学校の廊下回りの揭示物と教室周り での時間的変化について, 日本建築学会大会学術講演梗概集 E-1 分冊, pp. $71-72,1996.9$

14）斎藤潔，八木澤壮一，吉村彰：小学校の特別教室・職員室の壁面仕上げ 之掲示物の分析, 日本建築学会大会学術講演梗概集 E-1 分冊, pp. 293294, 1997.9

15）大崎淳史，吉村彰，刚屋信宏：小学校における情報伝達手段としての掲示 空間に関する研究，日本建築学会地域施設計画研究シンポジウム 地域施 設計画研究 29，pp. 115-122，2011.7

16）刚屋信宏, 吉村彰, 大崎淳史 : 小・中学校における揭示物に関する調查研 究，日本建築学会大会学術講演梗概集 E-1 分冊, pp. 571-572, 2011.8

17）大崎淳史, 吉村彰 : 中学校における情報伝達手段としての揭示空間に関す る研究, 日本建築学会地域施設計画研究シンポジウム 地域施設計画研究 30, pp. 115-122，2012.7

18）大崎淳史，吉村彰：小学校の校舎タイプによる掲示空間利用の比較 小 中学校における情報伝達手段としての揭示空間の計画に関寸る研究 そ の 1 , 日本建築学会計画系論文集，第 78 巻，第 684 号，pp. 335-344, 2013.2

19）しみん教育研究会:建築が教育を変える一福井市至民中の学校づくり物語, 鹿島出版会，2009.11

20）堀場弘，工藤和美:オープン・スペースの立体化，新建築，2006 年 10 月号, pp. 96-103, 2006. 10 